\title{
GLASS SAMPLING PROGRAM DURING DWPF INTEGRATED COLD RUNS (U)
}

by M. J. Plodinec

Westinghouse Savannah River Company

Savannah River Site

Aiken, South Carolina 29808

Other Authors:
WSRC-RP--90-100-Rev.1

DE93006328

This paper was prepared in connection with work done under Contract No. DE-AC09-89SR18035 I ith the U.S. Department of Energy. By acceptance of this paper, the publisher and/or recipient acknowledges the U.S.

Government's right to retain a nonexclusive, royalty-free license in and to any copyright covering this paper, along with the right to reproduce and to authorize others to reproduce all or part of the copyrighted paper. 


\section{DISCLAIMER}

This report was prepared as an account of work sponsored by an agency of the United States Government. Neither the United States Government nor any agency thereof, nor any of their employees, makes any warranty, express or implied, or assumes any legal liability or responsibility for the accuracy, completeness, or usefulness of any information, apparatus, product, or process disclosed, or represents that its use would not infringe privately owned rights. Reference herein to any specific commercial product, process, or service by rade name, trademark, manufacturer, or otherwise does not necessarily constitute or imply its endorsement, recommendation, or favoring by the United States Government or any agency thereof. The views and opinions of authors expressed herein do not necessarily state or reflect those of the United States Government or any agency thereof.

This report has been reproduced directly from the best available copy.

Available to DOE and DOE contractors from the Office of Scientific and Technicai Information, P.O. Box 62, Oak Ridge, TN 37831; prices available from (615) 576-8401, FTS 626-8401.

Available to the public from the National Technical Information Service, U.S. De:2arment of Commerce, 5285 Port Royal Rd, Springfield, VA 22161. 
WSRC-RP-90-100

Revision 1

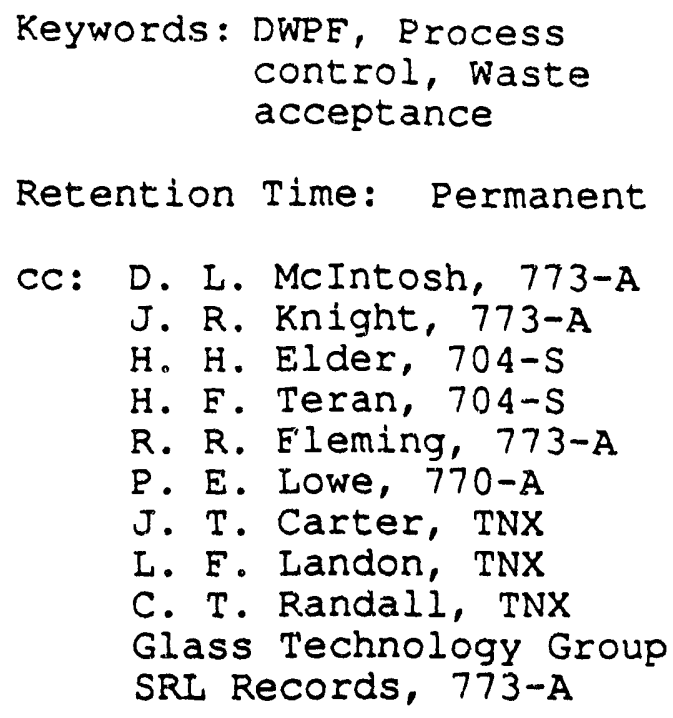

Keywords: DWPE, Process control, Waste acceptance

Retention Time: Permanent

CC: D. L. McIntosh, 773-A

J. R. Knight, 773-A

H. H. Elder, 704-S

H. F. Teran, 704-S

R. R. Fleming, 773-A

P. E. Lowe, 770-A

J. T. Carter, TNX

L. F. Landon, TNX

C. T. Randall, TNX

Glass Technology Group SRL Records, 773-A

March 30, 1990

To: J. R. Knight

From: M. J. Plodinec 
PABIT OE CONTENTS

\section{GLASS SAMPIING PROGRAM \\ DUA GG RHPF INTEGRATED COTR BUNS}

1. INTRODUCTICN AND SUMRARY 1

2. CBJECTIVES OF THE TEST PROGRAM 1

2.1. DWPF Product Compliance Strategy 2

2.2. Basis for Test Program 4

2.3. Availability of Process Information
Management System

3. TEST PROGRAM 5

3.1. Sampling and analysis of SME material 5

3.2. Sampling and analysis of MFT material 6

3.3. Sampling using the DWPF glass sampler 6

3.4. Sample unloading, and shipment to SRL 6

3.5. Canister sectioning 7

3.6. Sample characterization at SRI 8

4. SRECIAI REQUIREMENTS 9

4.1. Samplers - 9

4.2. Sample carrier 9

4.3. Saw for canisters 9

4.4. Doorstop 10

4.5. Cask 10

4.6. Canister archiving 10

5. QUALITY ASSURANCE PROGRAM ' 10

5.1. Organization 10

5.2. Program 10

5.3. Design control 11

5.4. Procurement document control 11

5.5. Instructions, procedures and drawings 11

5.6. Document control 15

5.7. Control of purchased items and services 16

5.8. Identification and control of items 16

5.9. Control of special processes 17

5.10. Inspection 17

5.11. Test control 18

5.12. Measuring and test equipment (M\&TE) 19

5.13. Handling, storage and shipping 20

5.14. Inspection, test and operating status 21

5.15. Control of nonconfurming items 21

5.16. Corrective action 22

5.17. Records 22

5.18. Audits and quality improvement 22 
5.19. Control of essential software

5.20. Control of experiments and developmental activities

5.21 . Selection, indoctrination and training of personnel

5.22. Modification control

6. REEERENCES

7. GLOSSARY

TABIE 1 - Canistar sectioning schedule

TABLE 2 - Participating Organizations

TABLI 3 - Elements to be Analyzed

in Glass Samples

28

FIGURE 1 - DWPF Compliance with Radionuclide Release Specification in the WAPS 
TO: J. R, KNIGHT

FROM :

M. J. PLODINEC

\section{GLASS SAMPIING PROGRAM \\ DURING DKPT INTEGRATED COTD RUNS}

\section{INTRODUCTION AND SUMMARY}

The repository program has established specifications for the DWPF pruduct. ${ }^{6.1}$ The most important of these, dealing with radionuclide release, require that the DWPF

- Control the process so that the glass product is capable of limiting release on the MCC-1 leach test 6.2 to less than 1 $\mathrm{g} / \mathrm{m}^{2} \cdot d$ (based on $\mathrm{Na}, \mathrm{Si}, \mathrm{B}, \mathrm{U}$, and $\mathrm{Cs}-137$ ),

- Verify that the glass product's radionuclide release properties has been controlled during production.

During actual operations, the DWPF will control the radionuclide release properties of the glass primarily through controliing the composition of the feed material in the Slurry Mix Evaporator. ${ }^{6.3}$ The DWPE will verify control of the radionuclide release properties through analysis of vitrified samples of Melter Feed Tank material. ${ }^{6.3}$ Confirmatory data will also be provided, based on analysis and testing (by SRL) of glass samples taken during production. In this report, a program is described which will demonstrate the DWPE's ability to effectively control and verify product quality in this manner. This test program will be carried out during the DWPE's Integrated Cold Runs.

\section{OBJECTIVES OF THE TEST RROGRAM}

The test program presented in section 3 is designed to achieve two objectives:

- To demonstrate DWPF's ability to control and verify the radionuclide release properties of the glass product.

- To confirm DWP''s readiness to obtain glass samples during production, and SRL's readiness to analyze and test those samples remotely.

The DWPF strategy for control of the radionuclide release properties of the glass product, and verification of its acceptability are described below. The basic approach of the test program is then defined. 
2.1. DNPE Product Compliance Strategy

2.1.1. Glass Product Control

The actions which will be performed during production to comply with the radionuclide release specification in the repository program's Waste Acceptance Preliminary Specifications, and the organizations which will perform them, are shown in Eigure 1. As noted above, the DWPF will control the radionuclide release properties of the glass primarily through controling the composition of the feed material in the Slurry Mix Evaporator (SME) .6.3 This requires performance of the following steps in order:

1) Sampling of the SME's contents after chemical additions have been completed, by DWPF Analytical Services.

2) Vitrification of the SME slurry samples, by DWPE Analytical Services.6.4

3) Chemical and glass redox analyses of the vitrified samples, by DWPF Analytical Services.

4) Calculation of the free energy of hydration from the compusition (done in the same manner as recommended for the Process Information Management System (PIMS) for Melter Feed Tank material) ${ }^{6.5}$

5) Comparison of the calculated free energy of hydration to the criterion for acceptability, by DWPE Technical. The criterion for acceptability is based on the free energy of hydration of the glass used in the Environmantal Assessment for the DWPF, and provides $95 \%$ confidence that $95 \%$ of the product will be at least as good as that glass. ${ }^{6.3}$

6) Adjustment of the contents of the SME if the criterion is exceeded (calculated free energy more negative than criterion), by DWPF Production, and repetition of the sampling and analysis cycle.

\subsubsection{Verification of Control}

The DWPE will verify that the radionuclide release properties of the glass product have been controlled through analysis of vitrified samples of Melter Feed Tank material. ${ }^{6.3}$ This is accomplished through performance of the following steps (Figure 1): 
1) Sampling of the MFT's contents, by DWPF Analytical Services.

2) Vitrification of the MFT slurry samples, by DWPF Analytical Services. ${ }^{6.4}$

3) Elemental and glass redox analyses of the vitrified samples, by DWPE Analytical Services.

4) Calculation of the free energy of hydration from the composition (done automatically within the Process Information Management System (PIMS)).6.5

5) Reporting of the calculated free energy of hydration and the glass composition expressed as oxides, by DWPF Production.

The cumulative errors of sampling and analysis must be small enough so that there is 95 confidence that 95 of the product is acceptable (this should be considered to be a 95 o upper tol'srance limit). Otherwise, additional feed or even glass samples are. required to provide the requisite confidence in the acceptability of the product.

\subsubsection{Confirmatory Glass Sampling}

During production, samples of glass taken during canister filling will be used to provide further confirmation of product acceptability (Figure 1). A modified canister throat protector has been designed which allows sampling of glass from the melter as it is being poured into the canister. When the canister is rotated away from the pouring position, the throat protector is removed from the canister by DWPF Production, and brought to a cell window for removal of the glass sample. The glass sample is packaged and labeled by DWPF Production, surveyed by Health Protection, and transported to SRL.

In SRL, the sample is removed from the packaging, and put into SRL's Shielded Cells Facility by SRL's Laboratory Services Section (ISS) personnel. There it is prepared for analysis and leach testing by LSS under the direction of Glass Technology personnel. The elemental composition of the glass sample is determined by SRL's Analytical Development Section, and reported to Glass Technology. Laboratory Services, under the direction of Glass Technology, confirms control of the radionuclide release properties of the glass by performing the DWPE 
Product Consistency Test 6.6 (PCT) on portions of the glass sample. Analysis of the test solution is performed by Analytical Development Section, and reported to Glass Technology. Glass Technology then reports all of the results to DWPE Technical.

The amount of glass sampling will be held to a The amount of glass sampling wing because of the difficulty
minimum during production, be handing highly radioactive glass samples in the
of handing DWPF. An important objective of the Integrated Cold Runs is to determine the frequency of glass sampling needed to satisfy the WAPS. If the DWPF can establish that the samples from the MFT provide $95 \%$ confidence that $95 \%$ of the product is acceptable, no glass sampling will be needed. However, if the MFT samples are not sufficient to satisfy the statistical criterion, glass sampling may be required to satisfy the WAPS.

\subsection{Basis for Test Program}

In order to achieve the program's objectives, it is necessary that the DWPF establish a relationship between. the composition of the feed to the melter and the acceptability of the glass in the canister, and between both of these and measurements made on the glass samples from the sampler in the throat protector.

According to the Waste Form Compliance Plan (WCP), 6.3 during the Integrated Cold Runs the DWPF will demonstrate that the actions described above are sufficient to ensure that the product is acceptable. The program outlined below achieves this by demonstrating that the chemical composition of the product (and, thus, the radionuclide release properties of the product) can be predicted from the chemical composition of the feed, and that a glass sample taken during pouring is representative of the glass in the canister. The former is a stronger condition than is required, but the approach has the advantage of providing additional assurance that the commitment in the WCP is met, without imposing additional effort on the DWPE.

The following assumptions were made in formulating the program. Six separate campaigns were assumed for the Integrated cold Runs, five using non-radioactive feed and one using feed doped with radioactive cesium. It was also assumed that these campaigns would produce a total of 124 canisters of glass ( 24 for campaign 1 , and 20 for each of the following campaigns). If the number of campaigns, the number of canisters in any of the 
campaigns, or the sequence of the campaigns changes, this program plan may need to be modified accordingly.

2.3. Availability of Process Information Management system

The test program has been written assuming that the DWPF Process Information Management system (PIMS) will be available for the campaigns. If it is not, the DWPF will need to manually record the information required by this program, in a manner which will allow ready retrieval and review.

\section{TEST PROGRAM}

The test program requires that the DWPF operate during the Integrated Cold Runs in the same manner as expected during radioactive operations. Thus, normal operating procedures are prerequisites for performance of the program. The program requires two deviations from normal operations. First, the program requires use of the glass sampler for every canister poured during the Integrated Cold Runs. Second, the program requires that the DWPF transport most of the canisters filled during the Integrated Cold Runs to SRL's TNX area, for sectioning and sampling of the glass in. the canister. Glass samples taken from the canisters will then be characterized by SRL.

During the Integrated Cold Runs, the steps to be fol.lowed fo each batch of material transferred to the MFT ace:

3.1. Sampling and analysis of SME material

Using the procedures which will be used during actual production, DWPE Analytical Services will sample the materia: in the SME. The sampling frequency for the first campaign will be based on testing performed at SRL; for subsequent campaigns, the experience from previous campaigns will be used to determine sampling frequency.

DWPF Analytical Services will vitrify these slurry samples, ${ }^{6.4}$ and then determine their elemental composition and $\mathrm{Fe}$ (II)/Fe(III) ratio, using the procedures to be followed during production. The analytical data will be reported through the PIMS, as will be done during production. ${ }^{6.5}$ DWPF Technical will determine the acceptability of the feed, as noted above. No feed will be transferred to the MFT unless it meets the criterion for acceptability. 
3.2. Sampling and analysis of $M E T$ material

Using the procedures which will be used during actual production, DWPF Analytical services will sample the material in the MFT. For the first campaign, only one sample will be required for each Mit batch. Eor subsequent campaigns, the experience from previous campaigns will be used to determine sampling frequency.

DWPF Analytical Services will vitrify these slurry samples, 6.4 and then determine their elemental composition and $\mathrm{Fe}$ (II)/Fe(III) ratio, using the procedures to be followed during production. The analytica. data will be reported through the PIMS, as will be done during production. ${ }^{6.5}$

3.3. Sampling using the DWPF glass sampler

During the Integrated Cold Runs, DWPF Production will use the DWPE glass sampler during filling of each canister. The sampling schedule for the first two campaigns should be set up so that samples are taken at different times during canister filling, to determine if. there is a preferred time during canister filling for sampling, based on glass sampler operability. For the rest of the Integrated Cold Runs, the time of sampling will be specified in the test procedures for each campaign (prepared in accordance with the Startup Manual ${ }^{6.7}$, , based on the experience from the first two campaigns. Production operating procedures will be used for sampling.

For all samples, the pouring conditions (pour temperature, date/time of sampling, canister number, pouring rate, weight of the canister at time of sampling), the sampler number, and the MF'T batch identification, will be reported in PIMS.

3.4. Sample unloading, and shipment to SRL

When the filled canister is rotated away from under the melter pour spout, DWPE Production will remove the glass sampler from the canister, using normal operating procedures. For most of the canisters, the DWPE will then transfer the sample to SRL in the most expeditious manner possible. For five of the canisters filled during the fifth campaign, and for all of the canisters filled during the sixth campaign (see section 5.5.1.4.1), the sampler will be brought to the Melt Cell wincow, and the glass sample will be unloaded into the sample carrier. The glass sample will then be placed into a package for shipment to SRL. The sample carrier 
March 30, 1990

Revision 1

and sampler will follow the same paths through the vitrification building that they will follow during actual prodiction, and production operating procedures will be used.

3.5. Canister sectioring

In order to establish that the glass sample taken from the pouring glass is representative of the canister contents, it is necessary to cut canisters open and take glass samples. This will be done in two ways: canister sectioning by sawing, and removal of the canister wall from the side of the canister. The schedule of canisters to be sectioned for each campaign is contained in the Canister Disposition $\mathrm{Plan} ;^{6.8}$ general selection criteria are summarized in Table 1.

3.5.1. Canister sectioning by sawing

For some of the canisters, the entire canister will be sliced into four sections (cylinders) by TNX Operations section (TOS), using the large band saw at TNX. One of the sections will be taken at a height corresponding to the level of the glass in the canister: when the glass sampler in the throat protector was used. As an alternative, Glass Technolog; is d TNX Operations will determine whether the canister can be cut once along the axis of the canister. Either method will provide adequate samples for characterization.

Glass samples will be taken from each section by Glass Technology for characterization. Canisters have been selected for sectioning for each of the following conditions: ${ }^{6.8}$

- Characterization of anticipated product produced under steady state conditions. During the Integrated Cold Runs, glass will be produced which represents two possible extreme waste compositions, which bound the property range the DWPE is designed to process. In addition, glass representing wastes within the anticipated operating range will also be produced. Limited replication ( 3 canisters) for characterization of each of these is provided.

- Characterization of product produced under conditions which represent the most rapid possible change in composition. This condition will occur for the initial period of each campaign, if the melter behaves as a well-stirred tank. ${ }^{6.9}$ Again, three canisters have been selected. If subsequent 
analyses show that the melter is not behaving as a well-stirred tank, then additional canisters will be sectioned which better represent this condition.

\subsubsection{Removal of anister wall}

In order to expedite characterization of the glass produced duriny the Integrated Cold Runs, most of the canisters will be opened for sampling by removing a section of the canister wall. TOS will accomplish this by using a welding torch, or other means, to cut a window at least 12 inches wide over the length of the canister (Twelve inches is specified to avoid affecting the glass to be sampled). Glass samples from each canister will be taken by Glass Technology for characterization.

\subsection{Sample characterization at SRL}

Once samples are received at SRI, all samples will be characterized by chemical analyses, glass redox determination, and Jeach testing using the PCT. Any crystalline phases present in glass samples taken from sectioned canisters will be identified, and their content determined.

Glass Technology is responsible for preparation of samples for characterization. For the last campaign, Laboratory Services personnel, working under the guidance of Glass Technology in the Shielded Cells Facility, will prepare the glass samples taken from the glass sampler. Samples will be submitted to SRL's Analytical Development Section for chemical analyses, and glass redox determinations, using DWPF procedures. The samples will also be analyzed by $x$-ray diffraction, to identify crystalline phases present in the glass to determine their content (vol of). Results will be reported to Glass Technology.

Glass samples will be leach tested using the PCT. Glass Technology is responsible for performance of the PCT. For the last campaign, Laboratory Services personnel, working under the guidance of Glass Technology in the Shielded Cells Facility, will perform the test. Analyses of the leachate will be performed by Analytical Development, and reported to Glass Technology. Glass Technology will collect all SRI results, interpret them, and then report the results and their interpretatior to DWPE Technical. An important firt of the interpretation will be comparison of the results of characterizing glass taken during canister filling with both the expected properties based on MFT analyses, and with the 
March 30, 1990

Revision 1

results of characterizing glass samples taken from sectioned canisters.

\section{SPECIAL REQUIREMENTS}

\subsection{Samplers}

DWPE will need to have a sufficient number of glass samplers available to allow every canister to be sampled during the Integrated Cold Runs. It is curr intly estimated that at least twelve will be needed. This is based on the following:

- At any time, up to four will be in plaze c canisters on the melter turntable.

- At least four should be ready to be placed 0.1 canisters on the turntable.

- At ary time, it is likely that four wi:" be being decontaminated after use (It is not necessiry that DWPE demonstrate decontamination of the sampler.).

The samplers will be used for all of the Integrated Cold Runs campaigns.

\subsection{Sample carrier}

DWPF must design and have fabricated a sample carrier so that glass samples removed from the sampler can be placed in the doorstop, for delivery to SRL. This sample carrier must be designed so that any necessary operations can be performed with manipulators. The sample carrier must have a unique identification, so that the path of the sample through the DWPE can be traced, if necessary. It is suggested that a prototype of the sample carrier be tested in SRL's Shielded Celis Facility. The sample carrier, and the procedures for sample handling, must minimize cross-contamination of the glass sample so that the recults of analyses and testing are not compromised.

\subsection{Saw for canisters}

A saw will be required for sectioning canisters (see section 3.5). The saw used for similar work at TNX is available, and satisfactory for this use. SRL's TNX operations (TOS) will be responsible for operation and maintenance of the saw, and for ensuring that there are sufficient supplies for its effective use (e.g., saw blades). Glass Technology will provide technical guidance. 
4.4. Doorstop

At the present time, it appears that a doorstop-type carrier is sufficient for safe handling and transfer of the glass samples from DWPE to SRL. Glass Technology is responsible for recommending a carrier to transfer glass samples from DWPE to SRL, based on avoidance of personnel radiation hazard. This recommendation, and its bases, will be documented as part of bases for the test plans for the fifth and sixth campaigns of the Integrated Cold Runs. It is recommended that the doorstop carrying the glass samples be uniquely identified for better traceability.

\subsection{Cask}

At the present time, there does not appear to be a need for a special cask for this program. Glass Technology is responsible for determining the need.

\subsection{Canister archiving}

Canisters will need to be archived until it has been determined that there is no further need for them. This includes the initial 18 produced, which will not be sectioned, and all of those which have been sectioned. This will be discussed more fully in the Canister Disposition Plan.

For all canisters delivered to TNX for sectioning, TOS will be responsible for archival. The canisters, and canister sections, must be protected from the elements, until it is determined that they are no longer needed.

\section{QUALITY ASSURAYCE PROGRAM}

\subsection{Organization}

The organizations participating in performance of this test program are listed in Table 2. The DWPF startup Group has overall responsibility for this test program, and delegates technical oversight of SRL activities to Glass Technology, and quality assurance oversight of SRL's activities to SRL's Quality Section (SRL QS). SRL QS will supply documentation of all overview activities to Waste Management Programs - Quality Section (WMP-Q).

\subsection{Program}

All activities described in this program plan will be carried out in accordance with the applicable requirements of DPSOP 257-2. According to this program 
description, WMP-Q is respunsible for oversight of organizations within Savannah River Operations which will participate in the program. SRL $Q S$ is responsible for oversight of organizations within Savannah River Laboratory which will participate in the program.

\subsubsection{Review}

This program has been reviewed by all of the organizations involved (Table 2). This program will also be subjected to independent peer review, according to Glass Technology procedure GT-QA-2-4.

\subsubsection{Qualification of data}

SRL's Process Modeling and Control Group, within Defense Waste Processing Technology Section, will review the results of the test program for technical accuracy. As appropriate, they will call on SRL's Scientific Computations section for assistance.

\subsection{Design control}

The glass sampler is a key to the success of this program. Its design is subject to DWPE's configuration control program, as described in DPSOP 257-2-3, section 3.2.3.

5.4. Procurement document control

Purchase of glass samplers is a Level 1 procurement. Preparation of the specification for procurement, and the rest of the procurement package, will be controlled as described in DPSOP 257-2-3, section 4.0. It may be necessary for SRL to procure glass analytical services outside WSRC. If so, this also will constitute a Level 1 procurement. If needed, preparation of the specification for procurement of glass analytical services, and the rest of the procurement package, will be accomplished as described in DPSOP 257-2-2, section 4.0 .

\subsection{Instructions, procedures and drawings}

5.5.1. S-Area procedures

\subsubsection{Feed analyses}

Feed analyses will be performed by DWPF Analytical Services personnel according to the 
procedures which will be used during production. The nonradioactive elements identified on the DWPF sampling schedule for the MFT will be analytically determined, and recorded by Analytical Services (a listing of elements is included in Table 3 ). The results will be archived by the DWPF PIMS. DWPF Analytical Services are responsible for development and control of these procedures.

5.5.1.2. Glass production

Glass will be produced using DWPE melter operating procedures. Melter Feed Tank batch identifications, data on feed rates and pour rates, canister numbers, date/time pouring was initiated and completed, date/time of sampling, and date/time of any process interrupts, will be recorded, and arcilived in the PIMS. DWPF Production is responsible for development and control of these procedures.

5.5.1.3. Glass sampling

5.5.1.3.1. Use of glass sampler

Procedures which will be used during actual production will be used to take glass samples. DWPF production is responsible for preparation and control of these procedures. The time when samples should be taken will be specified in the test plans for individual campaigns.

5.5.1.3.2, Canister sectioning

TNX Operations will be responsible for developing procedures for operation of the saw, and for opening windows in the side of canisters. These procedures will describe Glass Technology participation in key canister sectioning operations. Glass Technology personnel will be required to specify the location from which samples will be taken, and to take glass samples from the canister. 
5.5.1.4. Sample labelling, packaging, movement, and shipment to SRL

5.5.1.4.1. Samples from glass sampler

For all campaigns, DWPF will use the procedures which will be followed during production to control labeling, packaging, and movement of samples from the glass sampler through the DWPF. For campaigns 1 4, the samples will be carried to SRL in the most expeditious manner possible. During campaign 5, five glass samples will be transported to SRL in the same manner as radioactive samples, to test the readiness of DWPF to transport and deliver the samples, and of SRL to receive them. This will be done early in campaign 5, so that any problems can be identified and corrected early, and the adequacy of the solutions demonstrated.

For the last campaign, all operations necessary to prepare.the sample, and deliver it to SRI will be performed in the same manner as during production. DWPF Production is responsible for packaging and labelling glass samples, and arranging for $\mathrm{HP}-\mathrm{O}$ to survey the samples before shipment. DWPF Production is also responsible for arranging sample shipment to SRL. HP-O is responsible for surveying samples, and approving shipment. The procedures to accomplish this will be identified in the test plan for the last campaign as will the responsibilj.ty for their development and control.

\subsection{Canisters}

DWPF Production will be responsible for arranging shipment of filled canisters from DWPF to TNX. The planned use and disposition of each canister produced during the Integrated cold Runs is described in the Canister Disposition Plan. TNX Operations will be responsible for performing tests on the canisters (as described in the Canister Disposition Plan), and for sectioning them (as described in section 3.4). 
5.5.2. SRL procedures

5.5.2.1. Canister sectioning

TNX Operations will be responsible for canister sectioning, and thus for development of procedures to accomplish this. Glass Technology will provide technical guidance. The procedures to be used for sectioning canisters will specify the exact locations at which the canister will be cut. One of the cuts will be at the elevation corresponding to the level of the glass in the canister when the glass sampler was used.

Glass Technology is responsible for sampling sectioned canisters, see section 5.5.2.2.

5.5.2.2. Samples from canister sectioning

Glass Technology will remove samples from sectioned canisters. Glass Technology will be responsible for development and control of procedures governing sample selection, removal, packaging and labeling, and shipment to SRL. A control system for handiing samples from canister sectioning will be established by Glass Technology, and described in these procedures. This system will include provisions for sample archiving which satisfy the requirements of DPSOP 257-2-3, Section 8.2.

5.5.2.3. Samples from glass sampler

5.5.2.3.1. Receiving and acceptance

As noted above, SRL's Laboratory Services Section (LSS) is responsible for receipt and acceptance of samples from the glass sampler. In conjunction with Glass Technology, LSS will develop and implement procedures for use during actual production. These procedures will be used for receipt, acceptance, and handling of samples from the last Integrated Cold Runs campaign.

5.5.2.4. Sample archiving

Glass Technology is responsible for archiving glass samples from the Integrated Cold Runs. Glass Technology will develop and maintain procedures by which this will be accomplished. These procedures will satisfy the requirements of 
DPSOP 257-2-3, section 8.2 .

5.5.2.5. Sample characterization

$5 \cdot 5 \cdot 2 \cdot 5 \cdot 1$. Analyses

Glass Technology will submit samples labelled as described in section 5.8.3. The same elements analyzed for in the MFT will be determined for the glass samples. For samples from sectioned canisters, crystalline phases and their contents will be determined. All samples will be analyzed on a "Customer Assisted" basis. Analytical Development will follow the procedures used by the DWPF as closely as possible in analyzing samples from the Integrated Cold Runs. Samples from the last campaign will be treated as radioactive samples.

$5 \cdot 5 \cdot 2 \cdot 5.2$. Glass testing

All glass samples will be tested using the DWPE Product Consistency Test (PCT). Glass Technology is responsible for performance of the PCT. For the last campaign, LSS will perform the PCT in the shielded cells Facility using training, qualification, and testing procedures approved by Glass Technology.

5.5.2.5.3. Data interpretation

Glass Technology is responsible for collection and interpretation of data obtained from characterization of glass samples from the Integrated Cold Runs. A topical report containing the results and their interpretation will be issued by Glass Technology to DWPE Technical.

5.6. Document control

Each organization participating in the test program will control documents which they generate, according to their procedures. These procedures will be reviewed by WMP-Q (for SRO organizations) and by SRL QS (for SRL organizations) to ensure that they meet the requirements of DPSOP 257-2-3, section 6.0. Documents to be controlled will be specified in the test plans for each campaign. 
5.7. Control of purchased items and services

Procurement of glass samplers for this program will be controlled in the manner described in 257-2-3, section 7.0. It may be necessary for SRL to procure glass analytical services. If so, this will be a Level 1 procurement, accomplished as described in DPSOP 257-2-2, section 7.0 .

5.8. Identification and control of items

5.8.1. Glass samplers

Each sampler will be uniquely identified. DWPF Technical will establish and maintain a log for each sampler (procurement information, canisters on which it is used, time used). This will facilitate any later investigations of sampler failures.

Modification of the sampler (design, fabrication) must be controlled in accordance with the requirements of DPSOP 257-2-3, section 3.2.3.

5.8.2. Glass sample handling

Transfer of the glass sample to the sample carrier, and from thence to the doorstop will be accomplished in a manner which maintains the identity of the sample. A "manifest" system will be established, so that whenever the sample is transferred between locations in the DWPE, the manifest will be transferred as well.

5.8.3. Samples to be analyzed

All samples submitted to SRI's Analytical Development Section will be identified with the number of the canister from which the glass sample is taken. Samples from the glass sampler submitted for chemical analyses and redox determinations will have the prefix "GRAB." Samples removed from a sectioned canister, and submitted for chemical analyses and redox determinations will have the prefix "SECT." This will be followed by a code for the position of the sample in the canister. This code will consist of the distance between the sample location and the canister bottom, measured in inches, followed by an "H" (for height); and the distance between the sample wall and the sample location, measured in inches, followed by an " $R$ " (for radial). 
Leachate samples submitted for analyses will have the suffix "PCT." Thus, for example, a sample of the leachate from a PCT of a glass sample taken during pouring canister S00019 would be labeled "GRAB-S00019-PCT." As another example, a sample of the leachate from a PCT of a glass sample taken from a section of canister s00121 which is three feet from the canister bottom, and one inch in from the canister wall would be labeled "SECT-36H-1R-S00121-PCT."

5.8.4. Archival of samples

Glass Technology is responsible for archiving glass samples from the Integrated Cold Runs. Glass Technology will develop a system by which this will be accomplished which will ensure the traceability and retrievability of archived samples, in accordance with DPSOP 257-2-3, section 8.2.

\subsubsection{Archival of canisters}

TOS is responsible for archiving canisters of glass produced during the Integrated Cold Runs and delivered to TNX (Disposition of other canisters produced is discussed in the Canister Disposition Appendix of the DWPF Test Program Plan). TOS, in conjunction with Glass Technology, will develop a system by which this will be accomplished which will ensure that:

- Archived canisters are retained until it is determined that they are no longer needed.

- Archived canisters are protected from the elements so that they can later be sectioned for characterization, if needed.

This system will satisfy the requirements of DPSOP 257-2-3, Section 8.2.

5.9. Control of special processes

None of the operations performed as part of this program are special processes, as defined in $O G R / B-14$.

5.10. Inspection

DWPF Production will determine the need for inspection of the glass sampler, the sample carrier, and the container for shipping radioactive samples to SRL. If necessary, DWPE Production will establish inspection 
requirements in the procurement specifications.

\subsection{Test control}

For each of the Integrated Cold Runs campaigns, a test plan will be prepared by DWPE Technical, and adhered to by DWPF Production. These test plans will be prepared, reviewed, and approved as described in reference 6.6 .

5.11.1. Prerequisites
All of the special requirements in section 4 are prerequisites to performance of this program. All of the procedures identified in section 5.5 are also prerequisites.

5.11 .2 . Hold points

5.11.2.1.SME analyses

For each SME batch, the slurry must be held until the material has been analyzed, and the free energy of hydration calculated and found to be more positive than the criterion for glass acceptability. The checks on oxide mass balance, alkali to silica ratio, and target vs. analyses outlined in reference 6.4 should be utilized to determine whether individual analyses are acceptable. DWPF Technical is responsible for sampling, analyses, and determination of acceptability of analytical results and of SME material.

$5.11 .2 .2 . M F T$ analyses

For each MFT batch, the slurry must be held until the material has been sampled. The checks on oxide mass balance, alkali to silica ratio, and target vs. analyses outlined in reference 6.4 should be utilized to determine whether individual analyses are acceptable. DWPE Technical is responsible for sampling and analyses.

5.11.2.3.Glass sample

Before transfer of the custody of a glass sample, the receiver must accept the sample, based on the completeness of the documentation ("manifest") accompanying it. If the documentation is not acceptable, it must be corrected before the sample proceeds further. 


\subsubsection{Data collection}

$5.11 .3 .1 . \mathrm{SME}$

Required data from the SME samples include identification of the batch sampled, elemental composition and the $F e$ (II)/Ee(III) ratio of the material transferred to the MFT, a record of adjustments and reanalyses of the slurry, and the calculated free energy of hydration.

$5.11 .3 .2 \cdot \mathrm{MFT}$

Required data from the MFT samples include identification of the batch sampled, identification of the canisters filled with this batch, chemical composition on an oxide basis, $\mathrm{Fe}$ (II)/Fe(III) ratio (if measured), and the calculated free energy of hydration.

5.11.3.3.Glass samples

Required data for all glass samples include identification of the canister sampled, chemical composition of the glass, Fe(II)/Fe(III) ratio determination, data from performance of the Product Consistency Test, and the calculated free energy of hydration. For glass samples resulting from canister sectioning, identification of nonglassy phases and determination of their amount is also required.

\subsection{Measuring and test equipment (M\&TE)}

$5 \cdot 12 \cdot 1$. DWPF

This test program does not place any additional M\&TE requirements on the DWPF. However, melter and pour chamber thermocouples will constitute Category 1 M\&TE for this test program, as will the neutron glass level detection system. In addition, instruments used by DWPE Analytical Services to determine the chemical composition and redox state of the melter feed (including the oven used to vitrify slurry samples from the SME) are also Category 1 equipment.

$5.12 .2 . S R L$

This test program does not place any additional M\&TE requirements on SRL. However, instruments used by 
SRI.'s Analytical Development Section to delermine the chemical composition of the glass, to determine the redox state of the glass, and to identify crystalline phases present in glass samples from sectioned canisters, are Category 1 M\&TE.

Ovens used by Glass Technology for the PCT are also considered to be Category 1 M\&TE.

\subsection{Handling, storage and shipping}

\subsubsection{Samples from glass sampler}

5.13.1.1.Packaging

The package used during actual production must be sufficiently shielded to prevent exposure during handling and transport. Based on preliminary calculations, the glass sample can be safely transported in a doorstop-type carrier (Glass Technology is responsible for documenting these calculations as noted in section 4.4). DWPF Production, in conjunction with Glass Technology. and Laboratory Services personnel, will determine the actual packaging wich will be used. Sample transport to SRL will be tested for five canisters during the fith campaign, and then routinely performed during the sixth campaign. All other glass samples will be removed from the canister in the same manner as will be used during production, but will be transported to SRL in the most expeditious manner possible.

For the last campaign, DWPE Production will transfer the glass sample from the sample carrier into the doorstop, for shipment to SRL. This will be done in a manner which minimizes cross-contamination. HP-O in S-Area will survey samples before shipment to SRL. DWPF Production will be responsible for arranging transport.

\subsection{3 .1 .2$. Labelling}

Samples will be uniquely identified by the number of the canister from which they come. DWPE production will be responsible for maintaining sample traceability until they are delivered to SRL. The samples from the first four campaigns will be delivered to Glass Technology. For the samples from the fifth campaign used to demonstrate SRL's readiness to receive and analyze radioactive glass samples, the samples 
will be treated as radioactive materiai, and delivered to SRL's Laboratory Services. Once accepted by SRL, Glass Technology and Laboratory Services will be jointly responsible for maintaining sample traceability. Samples from the last campaign will be radioactive, and handled as such.

\subsubsection{Samples from canister sectioning}

5.13 .2 .1$. Packaging

There are no special packaging requirements for samples from the first four campaigns beyond those followed for transport and handling of non-radioactive material.

5.13 .2 .2$. Labelling

Samples will be uniquely identified by the number of the canister from which they come. Glass Technology will be responsible for maintaining sample traceability.

5.13.3. Sample transport

Glass Technology and DWPF Production are jointly responsible for determining the method for transporting samples from DWPE to SRL. This will be documented in individual test plans. The manifest from the DWPF will accompany the sample to SRL, and be used for transfers of the sample within SRL.

5.14. Inspection, test and operating status

Before each campaign, the melter (and any Category 1 measuring and test equipment which must be calibrated or standardized before each campaign) will be subjected to a preoperational inspection by DWPE Production.

DWPE Production will inspect the glass sampler before it is irserted in the canister to ensure operability. If the sampler is inoperable, it will be tagged as inoperable, and segregated.

The campaign will not be initiated until all items are in satisfactory operating condition.

5.15. Control of nonconforming items

Any individual participating in the test program who identifies a non-conforming condition is responsible for 
documenting that condition. Within SRL, the nonconformance is handled in the manner described in DPSOP 257-2-2, section 15.0. Within DWPF, the nonconformance is handled in the manner described in DPSOP 257-2-3, section 15.0 .

\subsection{Corrective action}

Any individual participating in the test program who identifies a significant condition adverse to quality is responsible for documenting that condition. The methods for identifying the significance of that condition, for generating a Corrective Action Report for significant conditions, and for ensuring that corrective action is taken, are described in DPSOP 257-2-3, section 16.0, for DWPF' and DPSOP 257-2-2, section 16.0, for SRI.

\subsection{Records}

Each organization participating in the test program will control records which they generate, according to their procedures. These procedures will be reviewed by WMP-Q to ensure that they meet the requirements of DRSOP 257-2-3, sections 17.1 and 17.2 . Records to be controlied will be specified in the test plans for each campaign.

At the completion of each campaign, DWPF Technical will prepare a records package containing originals or authonticated copies of the records from each participating organization. This package will provide a traceable and retrievable record of the performance of the test, and will be a lifetime record.

If the Process Information Management system is not available in time for these tests, DWPE Technical will be responsible for establishing a paper records system which is functionally equivalent to the PIMS. In this context, "functionally equivalent" means capable of carrying out the scope described in reference 6.5 .

5.18. Audits and quality improvement

All activities performed as part of this test program are subject to scheduled audits by ESH\&QA, and survelilances by ESH\&QA and the appropriate quality organization (WMP $-Q$ for DWPE; SRL $Q S$ for SRL). In addition, effectiveness evaluation practices are employed by both SRL (described in DPSOP 257-2-2, section 2.7.5), and DWPE (described in DPSOR 257-2-3, section 2.7 .5$)$ to guide quality improvement efforts. 
Marcb 30, 1990

Revision 1

5.19. Control of essential software

All of the modules within PIMS which are identified in this program plan will be subject to configuration control as described in DPSOP 257-2-3, section 3.2.1.

5.20. Control of experiments and developmental activities

None of the activities to be performed are actually experiments or developmental activities. However, actions performed by SRI in support of this test program will be performed in accordance with section 2-4 of the SRL QA Manual, and controlled as tasks.

5.21. Selection, indoctrination and training of personnel

All personnel who are responsible for performance of activities important to the success of this program will be selected based upon their management's appraisal of their ability to carry out their assigned functions. The systems for accomplishing this are described in DPSOP 257-2-2, sections 2.4 and 2.7.3, for SRL; and in DPSOP 257-2-3, sections 2.4 and 2.7 .3 , for DWPF.

5.22. Modification control

Modification of the glass sampler (design, fabrication) built into the throat protector will be controlled in accordance with the requirements of DPSOP 257-2-3, Section 3.2.3. This is the only item specific to this test program subject to the modification control requirements of $O G R / B-14$.

\section{RETERENCES}

6.1. Office of Civilian Radioactive Waste Management, Waste Accoptance Preliminary Specifications of the Defense Waste Processing Facility High-Level Waste Form, USDOE Report OGR/B-8, Revision 1, February, 1988.

6.2. J. E. Mendel (Compiler), Nuclear Waste Materials Bandbook-Waste rorm Test Methods, USDOE Report DOE/TIC-11400, Materials Characterization Center, Battelle-Pacific Northwest Laboratories, Richland, WA (1981).

6.3. A. I. Applewhite, "Revised Draft Waste Form Compliance Plan for the Defense Waste Processing Facility," DPST-86-746, Revision 7, July 15, 1988.

6.4. C. M. Jantzen, "Verification of Glass Composition and 
Strategy for SGM and DWPF Glass Composition Determination," DPST-86-708, March 30, 1987.

6.5. M. J. Plodinec, "Functional Description, DWPE Waste Acceptance Production Records," WSRC-RP-89-552, July 10 , 1989.

6.6. C. M. Jantzen, N. E. Bibler, "Product Consistency Test for DWPE Glass: Test Development and Protocol," DPST-87-575, July 30, 1987.

6.7. DWPT Startup Manual, SW4-3, Revision 0, December 20, 1989.

6.8. J. R. Harbour, "Canister Disposition Plan for the Integrated Cold Runs," WSRC-RP-90-359, March 23, 1990.

6.9. M. J. Plodinec, "Rate of Change of Glass Composition in DWPE Melters," DPST-85-944, December 10, 1985.

\section{GIOSSARY}

7.1. ADS: SRL's Analytical Development Section supports Glass Technology by performing analyses on glass samples. It is also responsible for development of procedures for DWPE to use for analysis of SME and MFT material.

7.2. Glass sampler: SRI, in support of the DWPF, has demonstrated use of a device for taking glass samples from the glass stream as it pours into the canister from the melter. The sampling device (essentially a shallow stainless steel "boat") is built into the canister throat protector.

7.3. Glass Technology: SRL's Glass Technology Group is responsible for characterization of the glass produced during the DWPF Test Program. It is also responsible for characterization of radioactive samples once production begins.

7.4. HP-O: Health Protection-Operations is responsible for ensuring that glass samples are moved from one location to another in a manner which will prevent release of contamination, and ensure that radiation doses to any individual as a result of that movement are within safe limits.

7.5. LSS: SRL's Laboratory Services Section is responsible for receipt of radioactive samples in SRL, and for operation of SRI's Shielded Cells Facility. 
7.6. MCC: The Materials Characterization Center is responsible for acting as a materials characterization resource for the DOE waste management community. Its primary focus has been development of test methodology and standards.

7.7. MFT: Feed is transferred from the Slurry Mix Evaporator to the Melter Feed Tank, and from thence to the melter.

7.8. PCT: The DWPF Product Consistency Test is a glass leach test developed by Glass Technology. It is used to demonstrate that the DWPF is consistently producing acceptable product.

7.9. PIMS: The Process Information Management System serves as the data archive for the DWPF.

7.10. SCF: SRL's Shielded Cells Facility, located in the basement of Building 773-A, contain the equipment. necessary to perform the PCT on radioactive samples, and prepare radioactive samples for analyses.

7.11. SME: The Slurry Mix Evaporator is the last DWPF feed preparation tank:

7.12. SRL QS: SRL's Quality Section is responsible for oversight of activities affecting quality performed by SRL, and its suppliers.

7.13. SRL: The Savannah River Laboratory is responsible for providing assistance to Savannah River Operations Division. In particular, several parts of SRL will perform actions in support of the DWPF during the DWPE Test Program.

7.14. TOS: SRL'S TNX Operations Section is responsible for operation of SRL's TNX area. It is also responsible for canister sectioning, and archiving.

7.15. WAPS: The Waste Acceptance Preliminary Specifications are established by DOE's repository program to ensure that the DWPE product will be acceptable for disposal in a licensed federal repository.

7.16. WCP: The Waste Form Compliance Plan describes the programs and activities the DWPE will perform to establish compliance with the WAPS.

7.17. WMP-Q: Waste Management Program-Quality is responsible for oversight of activities affecting quality performed by the DWPE, and its suppliers. 


\section{SABIE 1 \\ Canister sectioning schedule \\ Campaian 1}

Initial canisters will not be sectioned, but will be archived. Final six canisters will be characterized to provide baseline information for Campaign 2 .

\section{Campaign 2}

Three canisters from early in the campaign, and three from the end will be sectioned by sawing. The others will have a portion of the canister wall removed.

\section{Campaign 3}

Three canisters from early in the campaign, and three from the end will be sectioned by sawing. The canister which will be filled through the bottom drain valve will also be sectioned by sawing. The others will have a portion of the canister wall removed.

\section{Campaign 4}

Three canisters from early in the campaign, and three from the end will be sectioned by sawing. The canister which will be filled through the bottom drain valve will also be sectioned by sawing. The others will have a portion of the canister wall removed.

\section{Campaign 5}

Three canisters from early in the campaign, and three from the end will be sectioned by sawing. The canister which will be filled through the bottom drain valve will also be sectioned by sawing. The others will have a portion of the canister wall removed.

\section{Campatgn 6}

None of the canisters from this campaign will be sent to TNX for destructive examination. All will be sent to the GWSB . 


\section{TABLE 2}

\section{Rarticipating erganizations}

Savannah River Operations Division

Defense Waste Processing Facility Production

Defense Waste Processing Facility Technical

Analytical Services

Defense Waste Processing Eacility Startup

Waste Management Programs - Quality

Health Protection - Operations

Savannah River Laboratory

Defense Waste Processing Technology Section

Glass Technology

Process Modeling and Control

Analytical Development Section

Quality section

Laboratory Services Section

TNX Operations Section 


\title{
TABIE 3
}

\section{Elements to be Analyzed in Glass Samples*}

\author{
Al \\ B \\ $\mathrm{Ca}$ \\ $\mathrm{Fe}$ \\ $\mathrm{K}$ \\ Li \\ $\mathrm{Mg}$ \\ $\mathrm{Mn}$ \\ $\mathrm{Na}$ \\ Nd \\ $\mathrm{Ni}$ \\ Si \\ Ti
}

* Includes only those elements which would be reported $11 . e .$, those present at $\geq 0.5$ wto of the glass), and Nd, which will be added as a tracer in Campaign 2. For actual waste glass, Th and $U$ would be included, and Nd excluded. 
EIGURE 1

DWPE Compliance with Radionuclide Release Specification in the WAPS

$\begin{array}{ccc}\text { CONTROL OF } & \text { VERIFICATION OF } & \text { CONEIRMATION OF } \\ \text { RADIONUCLIDE } & \text { RADIONUCLIDE } & \text { RADIONUCIIDE } \\ \text { RELEASE } & \text { RELEASE } & \text { RELEASE }\end{array}$
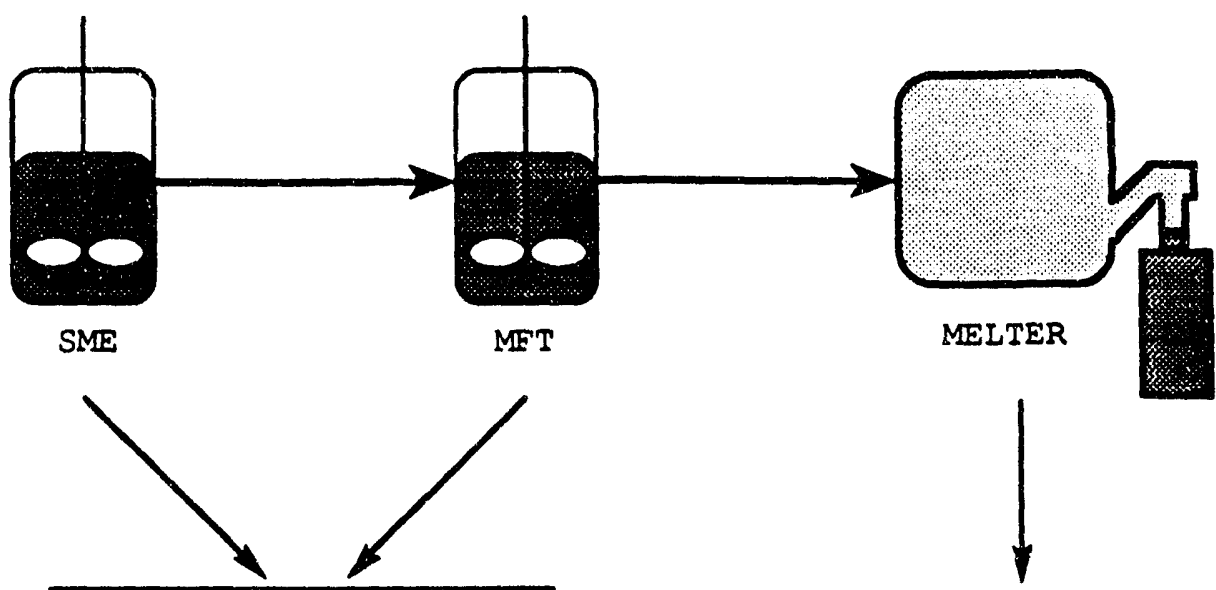

Sarmpled and analyzed by DWPE Technical Analytical Services

Analyzed for:

Major elements

Redox ratio

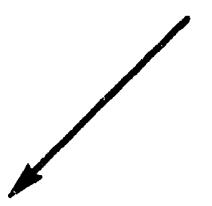

Acceptabil.1ty* determined by DWPE Technical Analytical Service

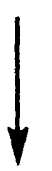

Necessary adjustments made by DWPF Production*

*Note: Feed must be acceptable before transfer to MFT is permitted.

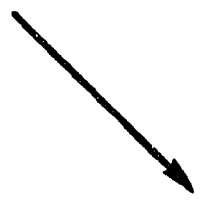

Acceptability verified by DWPE Technical Analytical Services

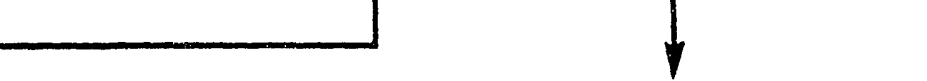

Glass sample analyzed by SRL Analytical Development; PCT done by Glass Technology

\section{Acceptability} DWPE Technical analytical Services reported by
Glass sample taken by DWPF Production
Glass sample accepted by SRL Lab. Services; aken to Shielded Cells

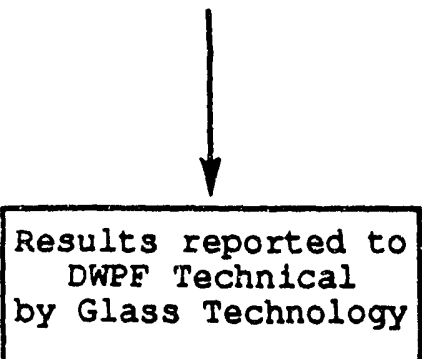




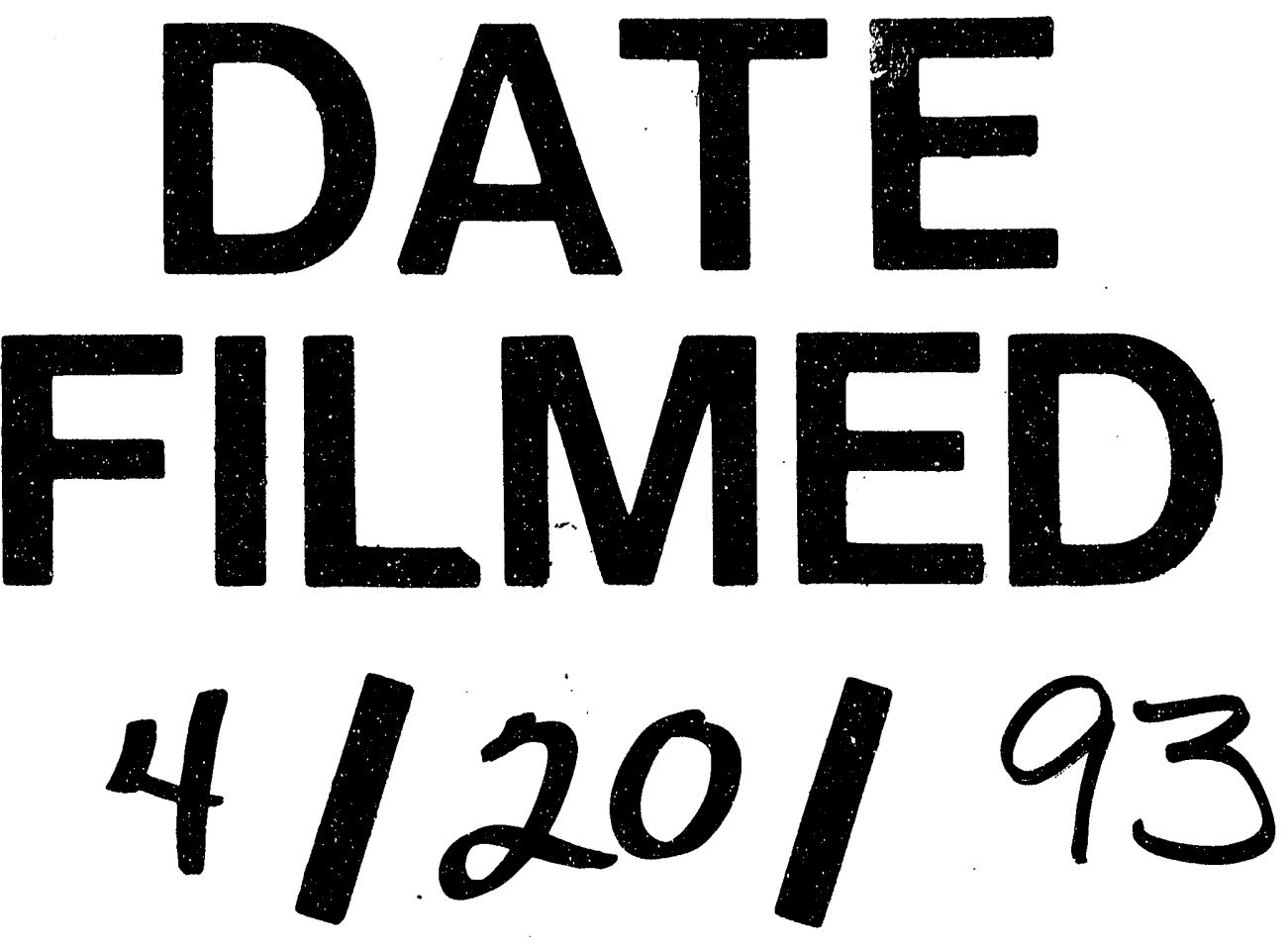


